\title{
Is there a long run relationship between stock returns and monetary variables: evidence from an emerging market
}

\author{
GÜLNUR MURADOG̃LU*, KIVILCIM METIN $\ddagger$ and \\ REHA ARGAÇ§
}

The Manchester School of Accounting and Finance, Manchester, UK, $\downarrow$ Department of Economics, Bilkent University, Ankara, Turkey and §YKB Bilgi Cagi Bankacilik Ussu, Optimus-2, Kocaeli, Turkey

Literature that provides empirical evidence about the long-term relationship between stock returns and monetary variables in emerging markets is limited. In those markets, unlike in mature ones, market participants and the availability of information as well as its quality, change rapidly through time. The purpose of this study is to examine the long-term relationship between stock returns and monetary variables in an emerging market through time by using the cointegration technique. The database is set up at daily frequency of variables that are customarily used by the financial media as determinants of stock investments and the cointegration technique enables us to consider changes in long-run steady-state properties of the equilibrium relationship between the non-stationary stock prices and monetary variables. The findings of this study indicate that, overall results should not be used in formulating investment strategies because they can be misleading in the sense that the variables that explain stock prices might change through time. In the case of ISE, as the market became more mature, the influence of monetary expansion and interest rates disappeared and foreign currency prices regained their expected significance.

\section{INTRODUCTION}

Cointegration is an attractive technique in examining financial markets due to the fact that it allows an analysis of the long run equilibrium relationship while accounting for the nonstationarity in financial time series. Many financial variables are known to exhibit unit roots (Nelson and Plosser, 1982) and differenced price series (return series) are used in traditional stock market studies. However, the Cointegration technique developed by Engle and Granger (1987), permits the use of individual time series at levels even if they are nonstationary. These variables are said to be cointegrated if their linear combination is stationary in levels. Cointegration, thus, implies a long-run equilibrium relation whereby deviations from this long-run equilibrium relation must eventually be corrected, since they are steady state.
The purpose of this study is to examine the long-run relationship between stock returns and monetary variables in an emerging market that evolved through time. In particular, the possible existence of a gradual change in long run steady state relationships at different stages of development is examined since the establishment of the Turkish Stock Market. In this analysis monetary variables are used as the relevant information set because of the overwhelming role of government in financial markets as well as the lack of firm specific information especially during the initial phases of development of the stock market. Changes in the long-run steady-state properties of the equilibrium relationship is tested by following Engle and Granger's (1987) two step cointegration approach.

This study is initiated by Fama's (1991) concluding remarks of his seminal survey article that encourages work '... that relates cross section properties of expected

* Corresponding author. E-mail: gulnur.muradoglu@man.ac.uk 
returns to the variation of expected returns, through time, and (...) relates the behaviour of expected returns to the real economy...' (Fama, 1991, p. 1610). In the literature, there are a limited number of studies explaining stock market behaviour by using the macroeconomic variables (Pearce and Roley, 1985; Darrat and Mukherjee, 1987; Darrat, 1988; Hancock, 1989; Bulmash and Trivoli, 1991) and even few that analyse the changes in market behaviour at different stages of development (Dawson, 1984; Muradog̃lu and Aydog̃an, 2001). The more recent use of cointegration methodology enables the analysis of the long run steady state properties of stock prices and macroeconomic variables in this context.

The distinguishing characteristic of this study is the use of daily data which permits the analysis of changes in the long run relationship between stock returns and monetary variables, if any, through time during the short history of the Turkish Stock Market. For that purpose, variables are used that are available on a daily basis, frequently used by the financial media and whose collection is not costly for investors (Mishkin, 1982). Different developmental phases of the market are defined in terms of the growth in size and transactions volume. Cointegration methodology enables us to separately analyse the long-run relationships through time by using the information revealed by the non-stationary financial variables. Although individual variables of concern may be non-stationary, their linear combinations might be stationary in cointegrating relations.

\section{THE SETTING}

Turkey went through a structural change from a government regulated economic regime to a market oriented one with the initiation of the IMF sponsored stabilization package in 1980. Part of this package was concerned with financial liberalization and integration of financial markets. The deregulation of interest rates, liberalization of the foreign trade regime, and convertibility of Turkish lira were among the first items in the agenda. In 1986, Istanbul Securities Exchange (ISE) became operational with 42 listed companies. Until a manual system was established at the end of 1987, trade floor activities were not limited to licensed brokers; individual investors could execute their orders directly. In 1989, with the aim of further liberalization, foreign investors were permitted to hold stock portfolios at ISE. Foreign participants who were mainly institutional investors expanded the volume of trade starting in 1990, and the market became highly sensitive to the foreign exchange rates. In 1993, computer aided trading procedures were introduced and this further increased volume of trade while insulating the market from insider traders. Since November 1994, all the stocks listed at ISE are traded by a computer assisted system. Today more than 200 stocks are traded during two sessions (morning and afternoon) every day and daily trading volume has exceeded \$100 million.

During the short history of the emerging Turkish stock market there are a limited number of studies explaining stock returns using macro-economic variables. Erol and Aydog̃an (1991) testing an arbitrage pricing model reported that portfolio returns are sensitive to unexpected inflation and real rate of return. Muradog̃lu and Önkal (1992) estimated separate equations to distinguish between expected and unexpected components of monetary and fiscal policy and reported a significant lagged relationship between these policy instruments and stock returns. Muradog̃lu and Metin (1996) using cointegration method and monthly values of various macro-economic variables reported that proxy effect was observed in the short run, while a real balance effect appeared in the long run equilibrium relationship. We were motivated with this finding in constructing a data base with higher frequency data and testing the long term relationship between stock returns and macro economic variables at different phases of market development. High frequency data are more informative in the sense that investment horizons are short in the highly inflationary environment of Turkey and stock investors are provided various descriptive information on the sensitivity of stock returns to interest rates, money and exchange rates by the financial media. Analyses are conducted at different phases as the market grows in size and volume to elude overall results obscuring possible changes in this relationship. If the underlying relationships changed through time, policy implications of short run analysis would no longer be valid.

\section{THE DATA}

The relationship between stock prices, represented by the ISE Composite Index and several monetary variables are examined. These variables are overnight interest rates, several definitions money supply (M1, M2 and currency in circulation), and foreign exchange rates of US dollar, German mark, British sterling and Japanese yen. In the choice of these variables two criteria are used: (1) availability of daily observations; and (2) high frequency of use by the financial media that makes data collection not costly for investors (Mishkin, 1982). Money supply variables represent monetary expansion in nominal terms which is expected to result in increased investments in stocks (Muradog̃lu and Metin, 1996). Interest rates and foreign exchange rates however, are included into the analysis as possible substitutes for stock investment (Muradog̃lu, 1992, 2000). The entire sample, from January 1988 to April 1995, consists of 1831 daily observations for $\log$ levels of each series.

The data set is divided into three sub-periods corresponding to different developmental phases based on the 
volume of trade in ISE. Summary information about stock market indicators are presented in Table 1. The first subperiod (1988-1989) represents the initial phase, where firmspecific information flow is poor, market participants are few and thus the volume of trade is low. The second subperiod (1990-1992) is characterized by the higher volume of trade generated mainly by foreign and domestic institutional investors. In this period the number of firms traded in the market has increased and information flow has improved through the introduction of various disclosure requirements. During the third sub-period (1993-1995), market expansion continued due to the considerable increase of the amount and quality of information by improved disclosure requirements. The introduction of computer aided trading mechanisms increased operational efficiency as well as the facilitating information dissemination.

Due to the uncertainties imposed by the structurally high inflation, term structures in Turkey are much shorter compared to those in mature markets. Market participants perceive one year as the long term, four months as the medium term and one week as the short term. ${ }^{1}$ Besides, during the research period, the maximum maturities of Tbills, range between 360 days to 120 days (Selcuk, 1995) and the maximum term structure for TL dominated as well as foreign exchange time deposits has been one year. It is also known that the average holding period for stock investments has been around three months (Muradoglu, 1992). Therefore, the sub-periods as defined previously can be considered as representing the long run for the Turkish stock market. Regarding the maturity structures of the Turkish economy on one side and the use of daily frequency in the data set on the other, we first analysed the stochastic properties of the data and then the long run relationship between the variables of concern by using the cointegration methodology at different sub-periods.

Stochastic properties of the data are investigated for each of the nine variables by applying the Augmented Dickey-Fuller(ADF) unit root test (Dickey and Fuller, 1981) at levels and first differences for the whole research period, as well as the three sub-periods. ADF values for each variable are calculated by estimating regression equations for a random walk, a random walk with drift and a random walk with drift and trend, respectively. For each estimation, Hsiao's (1981) final prediction error (FPE) model selection criteria is examined at lag lengths of 1 to 30 and the one with the smallest FPE is selected. In all cases, the variables have unit roots in levels i.e. they are not $I(0)$ at $1 \%$ significance. However, ADF test applied on the first differenced series do not exhibit a unit root, i.e. are $I(1)$ in almost all specifications. Table 2 reports ADF test results using Fuller's (1976) critical value for the $I(1)$ series, with the constant and trend specification. ${ }^{2}$ The possible existence of a long run relationship between the nonstationary stock prices and monetary variables, can thus be tested by using the cointegration technique developed by Engle and Granger (1987).

\section{COINTEGRATION ANALYSIS}

If $x_{t}$ donotes an $n x 1$ vector and each of series in $x_{t}$ are $I(d)$ and there exists an $n x 1$ vector $a$ such that $x_{t}^{\prime} a \sim I(d-b)$, then $x_{t}^{\prime} \cdot a \sim C I(d, b)$ where $a$ is called the cointegrating vector. An arbitrary linear combination of non-stationary time series $\left(y_{t}-a x_{t}\right)$ such as the ones described in Section II, is expected to be nonstationary. However, if these series are cointegrated, $a$ may take a value, such that $\left(y_{t}-a x_{t}\right)$ is

Table 1. Main indicators of ISE, exchange rates and monetary variables

\begin{tabular}{|c|c|c|c|c|c|c|c|c|c|c|}
\hline Year & $\begin{array}{l}\text { ISE* } \\
\text { annual } \\
\text { trading } \\
\text { volume }\end{array}$ & $\begin{array}{l}\text { ISE } \\
\text { \# of } \\
\text { listed } \\
\text { firms }\end{array}$ & $\begin{array}{l}\text { ISE } \\
\text { annual } \\
\text { change } \\
\text { in index }\end{array}$ & $\begin{array}{l}\text { Dollar } \\
\text { annual } \\
\% \\
\text { change }\end{array}$ & $\begin{array}{l}\text { Mark } \\
\text { annual } \\
\% \\
\text { change }\end{array}$ & $\begin{array}{l}\text { Yen } \\
\text { annual } \\
\% \\
\text { change }\end{array}$ & $\begin{array}{l}\text { Sterling } \\
\text { annual } \\
\% \\
\text { change }\end{array}$ & $\begin{array}{l}\text { M1 } \\
\text { annual } \\
\% \\
\text { change }\end{array}$ & $\begin{array}{l}\text { M2 } \\
\text { annual } \\
\% \\
\text { change }\end{array}$ & $\begin{array}{l}\text { Currency } \\
\text { annual } \\
\% \\
\text { change }\end{array}$ \\
\hline 1988 & 83 & 79 & $\%-46$ & $\% 77$ & $\% 58$ & $\% 75$ & $\% 71$ & $\% 48$ & $\% 71$ & $\% 57$ \\
\hline 1989 & 752 & 76 & $\% 494$ & $\% 28$ & $\% 34$ & $\% 12$ & $\% 14$ & $\% 81$ & $\% 81$ & $\% 93$ \\
\hline 1990 & 5226 & 110 & $\% 47$ & $\% 27$ & $\% 43$ & $\% 34$ & $\% 51$ & $\% 44$ & $\% 44$ & $\% 81$ \\
\hline 1991 & 8314 & 134 & $\% 34$ & $\% 74$ & $\% 72$ & $\% 87$ & $\% 70$ & $\% 45$ & $\% 62$ & $\% 44$ \\
\hline 1992 & 8378 & 145 & $\%-8.4$ & $\% 68$ & $\% 58$ & $\% 70$ & $\% 36$ & $\% 89$ & $\% 69$ & $\% 68$ \\
\hline 1993 & 21278 & 160 & $\% 417$ & $\% 69$ & $\% 58$ & $\% 88$ & $\% 65$ & $\% 66$ & $\% 50$ & $\% 71$ \\
\hline 1994 & 23203 & 176 & $\% 32$ & $\% 166$ & $\% 196$ & $\% 198$ & $\% 179$ & $\% 81$ & $\% 120$ & $\% 100$ \\
\hline $1995 * *$ & 4053 & 202 & $\% 75$ & $\% 11$ & $\% 25$ & $\% 32$ & $\% 15$ & $\% 17$ & $\% 33$ & $\% 34$ \\
\hline
\end{tabular}

Notes: Source: Capital Markets Board (1995), ISE (1995), Is Bankasi Data Base

* money values are in millions of US dollars

** only the first 2 months of 1995

\footnotetext{
${ }^{1}$ Interviews with several brokers and dealers.

2 Results do not change for other specifications of the model. Results are available from the authors upon request.
} 
Table 2. ADF test results

\begin{tabular}{|c|c|c|c|c|}
\hline SERIES & $\begin{array}{l}\text { For } \\
\text { whole period } \\
(1988-1995)\end{array}$ & $\begin{array}{l}\text { For } \\
\text { Period-1 } \\
(1988-1989)\end{array}$ & $\begin{array}{l}\text { For } \\
\text { Period-2 } \\
(1990-1992)\end{array}$ & $\begin{array}{l}\text { For } \\
\text { Period-3 } \\
(1993-1995)\end{array}$ \\
\hline DISE & $\begin{array}{l}-11.6464 * * \\
(9)\end{array}$ & $\begin{array}{c}-6.4349^{* *} \\
(10)\end{array}$ & $\begin{array}{l}-7.8574 * * \\
(9)\end{array}$ & $\begin{array}{c}-6.7807 * * \\
(13)\end{array}$ \\
\hline DINT. RATE & $\begin{array}{l}-10.1952 * * \\
(28)\end{array}$ & $\begin{array}{c}-6.2759^{* *} \\
(26)\end{array}$ & $\begin{array}{l}-5.2295^{* *} \\
(27)\end{array}$ & $\begin{array}{l}-5.3876^{* *} \\
(28)\end{array}$ \\
\hline DDOLLAR & $\begin{array}{l}-6.6158^{* *} \\
(23)\end{array}$ & $\begin{array}{c}-6.1590^{* *} \\
(20)\end{array}$ & $\begin{array}{l}-4.7007 * * \\
(20)\end{array}$ & $\begin{array}{l}-3.4898^{*} \\
(23)\end{array}$ \\
\hline DMARK & $\begin{array}{l}-6.5665^{* *} \\
(23)\end{array}$ & $\begin{array}{c}-4.6765^{* *} \\
(19)\end{array}$ & $\begin{array}{l}-5.7793 * * \\
(15)\end{array}$ & $\begin{array}{l}-3.4482^{*} \\
(23)\end{array}$ \\
\hline DYEN & $\begin{array}{l}-6.8389 * * \\
(23)\end{array}$ & $\begin{array}{c}-4.8990^{* *} \\
(19)\end{array}$ & $\begin{array}{l}-4.8762 * * \\
(27)\end{array}$ & $\begin{array}{l}-3.6492 * \\
(23)\end{array}$ \\
\hline DSTERLING & $\begin{array}{l}-6.5909 * * \\
(23)\end{array}$ & $\begin{array}{c}-4.8572 * * \\
\text { (19) }\end{array}$ & $\begin{array}{l}-5.5981 * * \\
(15)\end{array}$ & $\begin{array}{l}-3.5165^{*} \\
(23)\end{array}$ \\
\hline DMI & $\begin{array}{l}-8.6308 * * \\
(24)\end{array}$ & $\begin{array}{l}-5.4544^{* *} \\
\text { (19) }\end{array}$ & $\begin{array}{l}-5.4084 * * \\
(24)\end{array}$ & $\begin{array}{l}-4.8631 * * \\
(25)\end{array}$ \\
\hline DM2 & $\begin{array}{l}-5.7527 * * \\
(24)\end{array}$ & $\begin{array}{c}-4.9122 * * \\
\text { (19) }\end{array}$ & $\begin{array}{l}-5.2957 * * \\
(24)\end{array}$ & $\begin{array}{l}-3.2016 \\
(25)\end{array}$ \\
\hline DCURRENCY & $\begin{array}{l}-11.6172^{* *} \\
\text { (19) }\end{array}$ & $\begin{array}{l}-5.2812^{* *} \\
\text { (19) }\end{array}$ & $\begin{array}{l}-12.6270^{* *} \\
\text { (14) }\end{array}$ & $\begin{array}{l}-8.1613 * * \\
(17)\end{array}$ \\
\hline
\end{tabular}

Notes: (1) ADF test statistics reported here are based on regressions with constant and trend specification; (2) Each ADF regression initially includes thirty lagged differences to ensure that the residuals are empirically white noise. Then a sequential reduction procedure is applied to eliminate the insignificant lagged differences. Values in parentheses show the optimum number of lags used according to the FPE criteria; (3) D denotes log differences; (4) Critical values for ADF test statistics are obtained from Fuller (1976, Table 8.5.2); and (5) (*) denotes ADF test statistics significant at $5 \%$ and $(* *)$ significant at $1 \%$.

$I(0)$, indicating a stationary relationship between the variables. The null hypothesis of no cointegration (against the alternative of cointegration) is tested using the Engle and Granger (1987) two step procedure. The first step of this procedure involves regressing the stock prices on the monetary variables to obtain the OLS regression residuals. The second step is to test the existence of unit roots (i.e. no cointegration) in the OLS residuals using the ADF test. The results of ADF test statistics on cointegrating regressions (without constant and trend specification) are presented in Table 3 both for the whole research period and for the three sub-periods. The appropriate critical values are obtained from Engle and Granger (1987).

Stock prices do not cointegrate with any of the variables or with any group of variables for the whole research period. But this result is not valid for all sub-periods. During the first sub-period (1988-1989), stock prices do not cointegrate with any of the individual variables. The results are improved when more than one variable is added to the cointegrating regressions, with stronger results obtained in the interest rate, US dollar, M1 combination of independent variables. However, during the second sub-period (1990-1992), all the variables are cointegrated with the stock prices both when they enter to the regression equations individually and in groups. The results are improved substantially when, besides interest rates and M1, US dollar and Japanese yen are added to the regression equations. For this sub-period, a long run steady state relationship between monetary variables and stock prices is observed. During the third sub-period (1993-1995), none of the variables except for currency in circulation cointegrate with the stock prices individually. Better results are achieved when independent variables are entered in groups. The noticeable result is obtained when all variables are entered into the cointegrating relationship. The long run steady state relationship pursues during the 1993-1995 period but the result is weaker than that in the 1990-1991 period.

It is clear that, overall results in evaluating the long run relationships in emerging markets are misleading in the sense that they may indicate that a long run steady state relationship does not exist when in fact it does. Here, no cointegration relationship is found for whole research period. However, when the emerging market characteristics of ISE are considered and the research period is divided into three sub-periods, it is observed that the cointegrating relationships change through time. During the 1990-1992 period, there is a long run steady state relationship between stock returns and monetary variables which may indicate that the diligent investors can exploit abnormal profits at ISE by following monetary variables. Although diminished, profit opportunities still exist during the 1993-1995 period. At this point, one needs to identify the partial influence of the variables of concern. Therefore, static equations are estimated to show the changes in the size and sign of the parameters during the three sub-periods that indicate different developmental phases of the market. 
Table 3. Test of cointegration between stock prices and monetary variables

\begin{tabular}{|c|c|c|c|c|}
\hline $\begin{array}{l}\text { INDEPENDENT } \\
\text { VARIABLES }\end{array}$ & $\begin{array}{l}\text { For Whole } \\
\text { Period } \\
(1988-1995)\end{array}$ & $\begin{array}{l}\text { For } \\
\text { Period-1 } \\
(1988-1989)\end{array}$ & $\begin{array}{l}\text { For } \\
\text { Period-2 } \\
(1990-1992)\end{array}$ & $\begin{array}{l}\text { For } \\
\text { Period-3 } \\
(1993-1995)\end{array}$ \\
\hline US DOLLAR & $\begin{array}{c}-2.022 \\
(13)\end{array}$ & $\begin{array}{c}-0.407 \\
(11)\end{array}$ & $\begin{array}{c}-3.441 * \\
(10)\end{array}$ & $\begin{array}{l}-2.523 \\
(10)\end{array}$ \\
\hline GERMAN MARK & $\begin{array}{c}-1.916 \\
(10)\end{array}$ & $\begin{array}{c}-0.325 \\
(5)\end{array}$ & $\begin{array}{c}-3.423^{*} \\
(10)\end{array}$ & $\begin{array}{l}-2.669 \\
(10)\end{array}$ \\
\hline YEN & $\begin{array}{c}-1.814 \\
(13)\end{array}$ & $\begin{array}{l}0.027 \\
(11)\end{array}$ & $\begin{array}{c}-3.437^{*} \\
(10)\end{array}$ & $\begin{array}{l}-2.571 \\
(10)\end{array}$ \\
\hline STERLING & $\begin{array}{c}-1.988 \\
(13)\end{array}$ & $\begin{array}{c}-0.089 \\
(11)\end{array}$ & $\begin{array}{c}-3.419^{*} \\
(10)\end{array}$ & $\begin{array}{l}-2.6373 \\
(10)\end{array}$ \\
\hline M1 & $\begin{array}{c}-2.517 \\
(10)\end{array}$ & $\begin{array}{c}-1.568 \\
(20)\end{array}$ & $\begin{array}{c}-3.422 * \\
(10)\end{array}$ & $\begin{array}{l}-2.915 \\
(14)\end{array}$ \\
\hline M2 & $\begin{array}{c}-2.402 \\
(10)\end{array}$ & $\begin{array}{c}-1.092 \\
(11)\end{array}$ & $\begin{array}{c}-3.426^{*} \\
(10)\end{array}$ & $\begin{array}{l}-2.745 \\
(14)\end{array}$ \\
\hline CURRENCY & $\begin{array}{c}-2.692 \\
(20)\end{array}$ & $\begin{array}{c}-1.065 \\
(20)\end{array}$ & $\begin{array}{c}-3.417^{*} \\
(10)\end{array}$ & $\begin{array}{l}-3.236^{*} \\
(10)\end{array}$ \\
\hline INT. RATE & $\begin{array}{c}-1.459 \\
(9)\end{array}$ & $\begin{array}{c}-0.261 \\
(9)\end{array}$ & $\begin{array}{c}-3.456^{*} \\
(10)\end{array}$ & $\begin{array}{l}-1.496 \\
(16)\end{array}$ \\
\hline INT. RATE + DOLLAR + M1 & $\begin{array}{c}-2.825 \\
(20)\end{array}$ & $\begin{array}{l}-4.627 * * \\
\text { (5) }\end{array}$ & $\begin{array}{c}-3.773^{* * *} \\
(13)\end{array}$ & $\frac{-3.358 *}{(5)}$ \\
\hline INT. RATE + MARK + M1 & $\begin{array}{c}-2.812 \\
(20)\end{array}$ & $\begin{array}{c}-2.398 \\
(5)\end{array}$ & $\begin{array}{c}-3.587^{*} \\
(10)\end{array}$ & $\frac{-3.622 *}{(5)}$ \\
\hline INT. RATE + YEN + M1 & $\begin{array}{c}-2.842 \\
(20)\end{array}$ & $\begin{array}{c}-2.693 \\
(20)\end{array}$ & $\begin{array}{c}-3.834 * * \\
(10)\end{array}$ & $\frac{-3.197 *}{(5)}$ \\
\hline INT. RATE + STERLING + M1 & $\begin{array}{c}-2.785 \\
(20)\end{array}$ & $\begin{array}{c}-3.361 * \\
(5)\end{array}$ & $\begin{array}{c}-3.568^{*} \\
(10)\end{array}$ & $\frac{-4.432 *}{(5)}$ \\
\hline $\begin{array}{l}\text { INT. RATE + DOLLAR } \\
+ \text { MARK + M1 }\end{array}$ & $\begin{array}{l}-2.734 \\
(20)\end{array}$ & $\begin{array}{c}-3.41 * \\
(20)\end{array}$ & $\begin{array}{l}-3.974 * * \\
(10)\end{array}$ & $-3.619 *$ \\
\hline $\begin{array}{l}\text { INT. RATE + DOLLAR + MARK } \\
+ \text { YEN + STERLING + M1 }\end{array}$ & $\begin{array}{c}-2.697 \\
(20)\end{array}$ & $\begin{array}{c}-3.083 \\
(20)\end{array}$ & $\begin{array}{l}-4.047 * * \\
(10)\end{array}$ & $\begin{array}{l}-4.043 * * \\
(12)\end{array}$ \\
\hline
\end{tabular}

Notes: (1) The values reported here are the ADF test t-statistics based on regressions without constant and trend, (2) Each ADF regression initially includes thirty lagged differences to ensure that the residuals are empirically white noise. Then a sequential reduction procedure is applied to eliminate the insignificant lagged differences. Values in parentheses show the optimum number of lags used according to the FPE criteria results for the residuals of the related equations; (3) The critical values for the ADF test statistics are obtained from Engle and Granger (1987, Table 2); (4) (*) denotes ADF test statistics significant at 5\% and (**) significant at 1\% .

Static equations are estimated by using the contemporaneous values of the variables of concern and including constant, trend and four deterministic dummies representing the days of the week. In none of the equations deterministic dummies for daily seasonality appear to be significant. Equations are estimated both for the whole research period and the three sub-periods. Variables enter each equation first individually, and then in selected groups. Table 4 reports the static equations' estimation results. In almost all of the cases, as expected constant and trend variables are significant. Except for the second sub-period (19901992), the explanatory power of the independent variables are high as indicated by the goodness of fit measure of the equations. It is clear that during the second sub-period (1990-1992) most of the information that explains stock prices is left out from the specification. This period is characterized by the increase in the number of firms traded in the market and expansion of information flow through the introduction of various disclosure requirements. Investors can therefore be more concerned with the sudden and abundant flow of firm specific information. Thus, the static equations were re-estimated by using recursive least squares estimation and step dummies in this period. The first step dummy receives the value minus one for the points that lie outside the upper bound of the two standard error region, and zero elsewhere. The second step dummy receives the value of plus one for the points that lie outside the lower bound of the two standard error region and zero elsewhere. These dummies had significant coefficients in all the equations presented in Table $4 \mathrm{c}$. In all cases, goodness of fit measures improved but signs, sizes and significance of the parameters did not change.

Since foreign currencies are considered to be substitutes for stock investment (Muradog̃lu, 1992), we expect a reverse relationship between their price levels. Interest rate on short term deposits is proxied by the interbank overnight rates which are also expected to be negatively related to stock prices. Monetary variables indicate potential monetary expansion and are expected to be positively related to stock returns (Muradog̃lu and Metin, 1996). 
Table 4. Static equations $($ dependent variable $=$ lindex $)$

\begin{tabular}{|c|c|c|c|c|c|c|c|c|c|c|c|c|}
\hline $\mathrm{C}$ & TR & $\$$ & DM & YEN & ST & M1 & M2 & CUR & INT & $\mathrm{R}^{2}$ & DW & $\mathrm{F}$ \\
\hline \multicolumn{13}{|c|}{ 1. Whole period (1988-1995) } \\
\hline 8.122 & 0.0029 & -0.29 & - & - & - & - & - & - & - & 0.8869 & 0.0051 & 2385.1 \\
\hline 25.39 & 31.11 & -6.39 & & & & & & & & & & \\
\hline 6.923 & 0.0026 & - & -0.14 & - & - & - & - & - & - & 0.8849 & 0.0049 & 2337 \\
\hline 22.59 & 25.47 & & -2.74 & & & & & & & & & \\
\hline 0.599 & 0.0029 & - & - & -0.29 & - & - & - & - & - & 0.8882 & 0.0052 & 2411.3 \\
\hline 92.81 & 36.77 & & & -7.95 & & & & & & & & \\
\hline 7.729 & 0.0028 & - & - & - & -0.22 & - & - & - & - & 0.8856 & 0.0051 & 2349.7 \\
\hline 21.16 & 29.16 & & & & -4.52 & & & & & & & \\
\hline-18.12 & -0.003 & - & - & - & - & 2.78 & - & - & - & 0.9165 & 0.0143 & 3332.7 \\
\hline-19.54 & -15.29 & & & & & 26.51 & & & & & & \\
\hline-3.854 & 0.0002 & - & - & - & - & - & 1.036 & - & - & 0.8907 & 0.0054 & 2473.8 \\
\hline-4.002 & 0.508 & & & & & & 10.32 & & & & & \\
\hline-8.214 & -0.002 & - & - & - & - & - & - & 1.83 & - & 0.9038 & 0.0134 & 2851.8 \\
\hline-11.03 & -7.71 & & & & & & & 19.21 & & & & \\
\hline 6.156 & 0.0234 & - & - & - & - & - & - & - & -0.019 & 0.8844 & 0.0050 & 2321.1 \\
\hline 61.801 & 107.93 & & & & & & & & -0.755 & & & \\
\hline-21.56 & -0.004 & -0.576 & - & - & - & 3.51 & - & - & 0.266 & 0.9297 & 0.0415 & 3009.5 \\
\hline-23.19 & -17.25 & -15.15 & & & & 33.25 & & & 12.49 & & & \\
\hline-22.58 & -0.004 & - & -0.505 & - & - & 3.54 & - & - & 0.26 & 0.9269 & 0.0398 & 2887.4 \\
\hline-23.84 & -17.69 & & -12.33 & & & 32.35 & & & 12.06 & & & \\
\hline-24.1 & -0.004 & - & - & -0.45 & - & 3.45 & - & - & 0.26 & 0.930 & 0.0405 & 3030.1 \\
\hline-25.82 & -17.43 & & & -15.57 & & 33.04 & & & 12.39 & & & \\
\hline-21.31 & -0.004 & - & - & - & -0.52 & 3.47 & - & - & 0.27 & 0.927 & 0.0398 & 2900.3 \\
\hline-22.49 & -17.34 & & & & -12.66 & 32.24 & & & 12.27 & & & \\
\hline-20.04 & -0.004 & -1.36 & 0.87 & - & - & 3.33 & - & - & 0.25 & 0.931 & 0.0397 & 4938.3 \\
\hline-21.15 & -16.83 & -10.74 & 6.50 & & & 30.96 & & & 11.98 & & & \\
\hline-22.81 & -0.003 & -0.52 & 1.71 & -0.84 & -0.61 & 3.08 & - & - & 0.247 & 0.933 & 0.0375 & 3613.4 \\
\hline-19.35 & -16.55 & -2.84 & 7.27 & -6.35 & -3.1 & 27.0 & & & 11.82 & & & \\
\hline \multicolumn{13}{|c|}{ 2. First sub-period (1988-1989) } \\
\hline 54.83 & 0.013 & -6.92 & - & - & - & - & - & - & - & 0.87 & 0.086 & 1682.9 \\
\hline 52.35 & 52.83 & -46.62 & & & & & & & & & & \\
\hline 38.77 & 0.008 & - & -5.029 & - & - & - & - & - & - & 0.538 & 0.0204 & 291.6 \\
\hline 18.67 & 19.37 & & -15.77 & & & & & & & & & \\
\hline 16.14 & 0.008 & - & - & -4.54 & - & - & - & - & - & 0.84 & 0.0594 & 1314.4 \\
\hline 64.83 & 49.25 & & & -40.79 & & & & & & & & \\
\hline 43.09 & 0.008 & - & - & - & -4.84 & - & - & - & - & 0.81 & 0.0508 & 1073.2 \\
\hline 42.37 & 44.06 & & & & -36.47 & & & & & & & \\
\hline-31.82 & -0.008 & - & - & - & - & 4.368 & - & - & - & 0.70 & 0.0527 & 584.93 \\
\hline-21.52 & -20.43 & & & & & 25.59 & & & & & & \\
\hline-20.26 & -0.005 & - & - & - & - & - & 2.766 & - & - & 0.38 & 0.0074 & 153.38 \\
\hline-5.86 & -5.61 & & & & & & 7.59 & & & & & \\
\hline-6.99 & -0.002 & - & - & - & - & - & - & 1.67 & - & 0.409 & 0.0139 & 173.46 \\
\hline-4.97 & -4.89 & & & & & & & 9.24 & & & & \\
\hline 6.82 & 0.001 & - & - & - & - & - & - & - & -0.19 & 0.329 & 0.0152 & 123.08 \\
\hline 33.0 & 10.51 & & & & & & & & -3.97 & & & \\
\hline 32.48 & 0.007 & -5.52 & - & - & - & 1.48 & - & - & -0.094 & 0.899 & 0.098 & 1117.6 \\
\hline 14.5 & 13.34 & -30.66 & & & & 10.93 & - & & -5.0 & & & \\
\hline-9.21 & -0.003 & - & -2.17 & - & - & 3.48 & - & - & -0.17 & 0.739 & 0.0586 & 352.56 \\
\hline-2.82 & -4.28 & & -7.34 & & & 17.69 & & & -5.58 & & & \\
\hline 5.32 & 0.004 & - & - & -3.76 & - & 1.13 & - & - & -0.16 & 0.867 & 0.0993 & 818.28 \\
\hline 2.97 & 7.27 & & & -24.36 & & 6.49 & & & -7.36 & & & \\
\hline 23.15 & 0.003 & - & - & - & -3.78 & 1.45 & - & - & -0.17 & 0.849 & 0.0748 & 702.7 \\
\hline 8.47 & 5.40 & & & & -21.44 & 8.01 & & & -7.16 & & & \\
\hline 31.45 & 0.007 & -5.60 & 0.195 & - & - & 1.52 & - & - & -0.09 & 0.900 & 0.0978 & 894.14 \\
\hline 12.69 & 12.04 & -28.3 & 0.96 & & & 10.81 & & & -4.69 & & & \\
\hline 15.58 & 0.005 & -2.2 & 3.99 & -2.27 & -2.73 & 0.73 & - & - & -0.09 & 0.929 & 0.12 & 930.49 \\
\hline 4.57 & 8.85 & 7.42 & 12.66 & -5.17 & -6.07 & 5.58 & & & -5.35 & & & \\
\hline
\end{tabular}


Table 4. continued

\begin{tabular}{|c|c|c|c|c|c|c|c|c|c|c|c|c|}
\hline $\mathrm{C}$ & TR & $\$$ & DM & YEN & ST & M1 & M2 & CUR & INT & $\mathrm{R} 2$ & DW & $\mathrm{F}$ \\
\hline \multicolumn{13}{|c|}{ 3. Second sub-period (1990-1992) - estimated with step dummies } \\
\hline 21.45 & 0.003 & -1.72 & - & - & - & - & - & - & - & 0.326 & 0.089 & 71.382 \\
\hline 27.51 & 16.57 & -16.91 & & & & & & & & & & \\
\hline 5.63 & -0.001 & - & 0.37 & - & - & - & - & - & - & 0.037 & 0.039 & 5.72 \\
\hline 5.57 & -2.70 & & 2.61 & & & & & & & & & \\
\hline 12.65 & 0.004 & - & - & -1.66 & - & - & - & - & - & 0.223 & 0.074 & 42.33 \\
\hline 35.41 & 12.07 & & & -12.25 & & & & & & & & \\
\hline 4.25 & -0.001 & - & - & - & 0.491 & - & - & - & - & 0.224 & 0.071 & 35.52 \\
\hline 5.01 & -4.75 & & & & 4.75 & & & & & & & \\
\hline 2.68 & -0.001 & - & - & - & - & 0.57 & - & - & - & 0.227 & 0.073 & 43.83 \\
\hline 2.70 & -5.62 & & & & & 5.63 & & & & & & \\
\hline 11.5 & 0.001 & - & - & - & - & - & -0.30 & - & - & 0.083 & 0.060 & 11.03 \\
\hline 5.66 & 1.57 & & & & & & -1.59 & & & & & \\
\hline 2.77 & -0.001 & - & - & - & - & - & - & 0.61 & - & 0.310 & 0.100 & 47.49 \\
\hline 4.63 & -9.0 & & & & & & & 9.19 & & & & \\
\hline 7.50 & -0.000 & - & - & - & - & - & - & - & 0.194 & 0.157 & 0.078 & 22.96 \\
\hline 69.03 & -4.118 & & & & & & & & 7.042 & & & \\
\hline 16.5 & 0.002 & -1.33 & - & - & - & 0.16 & - & - & 0.095 & 0.302 & 0.086 & 39.71 \\
\hline 9.54 & 6.047 & -11.33 & & & & 1.46 & & & 3.33 & & & \\
\hline-6.90 & -0.003 & - & 1.21 & - & - & 0.54 & - & - & 0.34 & 0.174 & 0.062 & 22.17 \\
\hline-4.39 & -9.63 & & 7.81 & & & 5.03 & & & 10.43 & & & \\
\hline 7.50 & 0.002 & - & - & -1.14 & - & 0.343 & - & - & 0.104 & 0.228 & 0.076 & 27.13 \\
\hline 5.12 & 3.64 & & & -6.87 & & 2.94 & & & 3.17 & & & \\
\hline-10.01 & -0.004 & - & - & - & 0.80 & 1.09 & - & - & 0.26 & 0.428 & 0.127 & 61.15 \\
\hline-7.52 & -13.41 & & & & 8.70 & 11.71 & & & 11.15 & & & \\
\hline 7.22 & -0.001 & -1.64 & 1.82 & - & - & -0.05 & - & - & 0.25 & 0.390 & 0.0933 & 78.64 \\
\hline 4.45 & -1.74 & -15.86 & 13.38 & & & -0.45 & & & 8.83 & & & \\
\hline 6.75 & -0.001 & -1.53 & 1.58 & -0.23 & 0.276 & -0.07 & - & - & 0.23 & 0.449 & 0.106 & 37.01 \\
\hline 3.59 & -0.7 & -10.73 & 9.89 & -1.2 & 2.46 & -0.62 & & & 7.61 & & & \\
\hline \multicolumn{13}{|c|}{ 4. Third sub-period (1993-1995) } \\
\hline 14.4 & 0.005 & -0.63 & - & - & - & - & - & - & - & 0.89 & 0.031 & 2377 \\
\hline 29.29 & 28.29 & -11.52 & & & & & & & & & & \\
\hline 15.58 & 0.006 & - & -0.82 & - & - & - & - & - & - & 0.91 & 0.041 & 2828.8 \\
\hline 36.2 & 32.78 & & -15.9 & & & & & & & & & \\
\hline 11.01 & 0.005 & - & - & -0.54 & - & - & - & - & - & 0.88 & 0.028 & 2208.6 \\
\hline 45.3 & 23.65 & & & -9.36 & & & & & & & & \\
\hline 15.3 & 0.006 & - & - & - & -0.7 & - & - & - & - & 0.90 & 0.034 & 2503.7 \\
\hline 30.1 & 29.2 & & & & -12.9 & & & & & & & \\
\hline 8.98 & 0.003 & - & - & - & - & -0.02 & - & - & - & 0.87 & 0.021 & 1880.5 \\
\hline 7.19 & 12.4 & & & & & -0.19 & & & & & & \\
\hline 18.56 & 0.005 & - & - & - & - & - & -0.82 & - & - & 0.89 & 0.027 & 2360.3 \\
\hline 21.4 & 27.2 & & & & & & -11.3 & & & & & \\
\hline 10.88 & 0.004 & - & - & - & - & - & - & -0.21 & - & 0.87 & 0.022 & 1895.5 \\
\hline 10.24 & 14.3 & & & & & & & -2.0 & & & & \\
\hline 8.83 & 0.003 & - & - & - & - & - & - & - & -0.02 & 0.87 & 0.022 & 1887.1 \\
\hline 125.65 & 61.3 & & & - & & & & & -1.34 & & & \\
\hline 15.21 & 0.006 & -0.68 & - & - & - & -0.05 & - & - & 0.03 & 0.89 & 0.033 & 1199.3 \\
\hline 10.37 & 16.59 & -11.67 & & & & -0.39 & & & 1.82 & & & \\
\hline 14.39 & 0.006 & - & -0.84 & - & - & 0.11 & - & - & 0.03 & 0.91 & 0.043 & 1417.8 \\
\hline 10.8 & 19.3 & & -15.9 & & & 0.98 & & & 1.75 & & & \\
\hline 11.36 & 0.005 & - & - & -0.56 & - & -0.03 & - & - & 0.017 & 0.88 & 0.029 & 1104 \\
\hline 7.74 & 15.1 & & & -9.25 & & -0.24 & & & 0.89 & & & \\
\hline 15.1 & 0.006 & - & - & - & -0.74 & 0.036 & - & - & 0.033 & 0.897 & 0.037 & 1257.8 \\
\hline 10.58 & 17.37 & & & & -12.93 & 0.29 & & & 1.83 & & & \\
\hline 9.22 & 0.005 & 2.06 & -2.77 & - & - & 0.41 & - & - & -0.03 & 0.924 & 0.0622 & 1405.0 \\
\hline 7.14 & 18.63 & 11.22 & -15.5 & & & 3.77 & & & -1.81 & & & \\
\hline 19.36 & 0.004 & 0.27 & -3.44 & 2.21 & 0.34 & 0.32 & - & - & -0.03 & 0.942 & 0.0799 & 1335.6 \\
\hline 14.18 & 16.81 & 0.84 & -16.7 & 13.31 & 0.89 & 3.32 & & & -2.26 & & & \\
\hline
\end{tabular}


Table 4. continued

\begin{tabular}{|c|c|c|c|c|c|c|c|c|c|}
\hline & Index & INT & $\$$ & $\mathrm{DM}$ & YEN & ST & M1 & M2 & CUR \\
\hline \multicolumn{10}{|c|}{ 5. Degree of correlation between the variables } \\
\hline Index & 1 & & & & & & & & \\
\hline INT & 0.2452 & 1 & & & & & & & \\
\hline$\$$ & 0.9365 & 0.3255 & 1 & & & & & & \\
\hline $\mathrm{DM}$ & 0.9422 & 0.2930 & 0.9968 & 1 & & & & & \\
\hline YEN & 0.9465 & 0.3022 & 0.9965 & 0.9985 & 1 & & & & \\
\hline ST & 0.9366 & 0.3095 & 0.9986 & 0.9985 & 0.9967 & 1 & & & \\
\hline M1 & 0.9591 & 0.2487 & 0.9714 & 0.9730 & 0.9690 & $\begin{array}{l}0.972 \\
0\end{array}$ & 1 & & \\
\hline M2 & 0.9574 & 0.2166 & 0.9751 & 0.9824 & 0.9781 & $\begin{array}{l}0.978 \\
3\end{array}$ & 0.9928 & 1 & \\
\hline CUR & 0.9576 & 0.2612 & 0.9779 & 0.9796 & 0.9763 & $\begin{array}{l}0.978 \\
5\end{array}$ & 0.9977 & 0.9929 & 1 \\
\hline
\end{tabular}

Notes: (1) Four deterministic dummies for seasonality (day of the week effect) are added to the equations; (2) In each cell, first row gives the beta coefficients and the second row gives the corresponding $t$-statistics; (3) The following symbols denote: C: constant; TR: trend; $\$$ : dollar; DM: mark; ST: sterling; CUR: currency in circulation; INT: interest rate; DW: Durbin Watson Statistics; F: F-test; and (4) All static estimations relate to contemporaneous values of the variables.

Considering the whole research period (where no cointegrating relationship is found) presented in Table $4 \mathrm{a}$, it is observed that except for the insignificant interest rate coefficient all of the variables of concern are significant and have expected signs. Similar to the overall research period, during the first sub-period (1988-1989) all of the variables used in static equations have significant coefficients and expected signs. The second sub-period (1990-1992), for which it is safely argued that stock prices and the monetary variables are cointegrated needs to be focused. In the bivariate regressions, money supply and the interest rate both have positive and significant coefficients. The signs of the German mark and British sterling coefficients also become positive in this period. When fund portfolios are investigated, it is evident that a representative portfolio carries T-bills with weights exceeding $80 \%$ (ISE, 1995). When individual stock investors' portfolios are considered it is noticed that foreign exchange holdings constitute a major portion of their portfolios (Muradog̃lu, 1992). Diversification using foreign exchange and T-bills might explain the unexpected sign changes observed in the 1990-1992 period. During the third sub-period (19931995) money supply and interest rates do not have significant coefficients but all foreign exchange rate variables' coefficients are significant and have expected signs. In this period market expansion continued and as the market became more mature, the influence of monetary expansion and interest rates disappeared and foreign currency prices regained their expected signs.

\section{CONCLUSIONS}

Literature that provides empirical evidence about a potential change in the long run relationship between stock returns and macro-economic variables in emerging markets is limited. In those markets, unlike in mature ones, market structures, market participants and the availability of information as well as its quality change rapidly through time. Therefore, results regarding the whole research period may lead to incorrect evaluations as to the relationship between the variables. Due to such misleading interpretations, profitable investment strategies may be abandoned. This study investigates the relationship between stock prices and monetary variables at different phases of development of ISE represented in three sub-periods during 1988-1995. For that purpose we use the cointegration technique that enables us to examine the long run relationship between the non-stationary stock prices and monetary variables. The data base is set up at daily frequency of variables that are customarily used by the financial media as determinants of stock investments.

Results regarding the whole research period (1988-1995) display no cointegrating relationship between stock prices and any of the variables or groups of variables of concern. But overall results are misleading for investors who would like to exploit profit opportunities in the sense that such occasions exist, despite expectations, especially as the market develops over time. The only sub-period that the stock prices do not cointegrate with monetary variables is the first sub-period (1988-1989). However, while during the second sub-period (1990-1992) all variables are cointegrated with stock prices both individually and in groups, during the third sub-period (1993-1995) only groups of variables are cointegrated with stock prices.

The diligent investor who wants to exploit profit opportunities in emerging stock markets should consider the rapidly changing characteristics of such markets. First, overall results should not be used in formulating long run investment strategies because they can be misleading in the 
sense that they may assume the existence of a relationship when in fact it does not exist. Second, investors should be aware that the variables that explain stock prices might change through time. In the case of ISE, as the market became more mature, the influence of monetary expansion and interest rates disappeared and foreign currency prices re-gained their expected significance.

We would expect future work in this area to concentrate on the following research avenues. First, modelling efforts should be extended to accommodate error correction specification that enables the analysis of short run dynamics together with the long run steady state properties. Second, research in other emerging markets are expected to contribute to our understanding of common trends in the long run relationship between stock returns and monetary variables. Finally, country comparisons of emerging versus mature markets will guide researchers and investors in identifying the market structures that lead to differences in the form of the long run relationship between stock returns and monetary variables.

\section{REFERENCES}

Bulmash, B. S. and Trivoli, W. G. (1991) Time-lagged interactions between stock prices and selected economic variables, The Journal of Portfolio Management, Summer, 61-7.

Dawson, S. M. (1984) The trend toward efficiency for less developed stock exchanges: Hong Kong, Journal of Business Finance and Accounting, 11(2), 151-61.

Darrat, A. F. (1988) On fiscal policy and the stock market, Journal of Money Credit and Banking, 20, 355-63.

Darrat, A. F. and Mukherjee, T. K. (1987) The behaviour of the stock market in a developing economy, Economics Letters, 22, 273-8.

Dickey, D. A. and Fuller, W. A. (1981) Likelihood ratio statistics for autoregressive time series with a unit root, Econometrica, 49, 1057-72.

Engle, R. F. and Granger, C. W. (1987) Cointegration and error correction: representation, estimation, and testing, Econometrica, 55, 251-76.
Erol, Ü and Aydog̃an, K. (1991) Asset pricing in an emerging market: the Turkish case, paper presented in the 18th Annual Meeting of European Finance Association, held in Rotterdam, Holland.

Fama, E. F. (1991) Efficient capital markets: II, Journal of Finance, 46, 1575-617.

Hancock, D. G. (1989) Fiscal policy, monetary policy and the efficiency of the stock market, Economics Letters, 31, 65-9.

Hsiao, C. (1981) Autoregressive modelling and money income causality detection, Journal of Monetary Economics, 7, 85106.

Istanbul Securities Exchange, Monthly Bulletin, December 1995.

Mishkin, F. S. (1982) Does anticipated monetary policy matter? An econometric investigation, Journal of Political Economy, 90, 22-51.

Muradog̃lu, G. (1992) Factors influencing demand for stocks by individual investors, Proceedings of Izmir Iktisat Kongresi, vol. 1.

Muradog̃lu, G. (2000) Turkish Stock Market Anomalies and Profit Opportunities, Security Market Imperfections in Worldwide Equity Markets (Ed. Keim, D. and Ziemba, W.), 364-390.

Muradog̃lu, G. and Aydog̃an, K. (2001) Price reactions to the implementation of stock dividends and rights offerings: efficiency of Turkish stock market through time, European Journal of Finance, 7, 1-20.

Muradog̃lu, G. and Önkal, D. (1992) Semi-strong form of efficiency in the Turkish stock market, METU Studies in Development, 19(2), 197-208.

Muradog̃lu, G. and Metin, K. (1996) Efficiency of the Turkish stock exchange with respect to monetary variables: a cointegration analysis, European Journal of Operational Research, 90, 566-76.

Nelson, C. R. and Plosser, C. I. (1982) Trends and random walks in macroeconomic time series: some evidence and implications, Journal of Monetary Economics, 10, 139-62.

Pearce, D. K. and Roley, V. V. (1985) Stock Prices and Economic News, Journal of Business, 8(1), 49-67.

Selçuk, F. (1995) The Term Structure of Interest Rates in High Inflation Environment: Some Evidence from Turkey, Paper Presented at the EEA Conference, March 17-19, New York, NY. 
Copyright of Applied Financial Economics is the property of Routledge and its content may not be copied or emailed to multiple sites or posted to a listserv without the copyright holder's express written permission. However, users may print, download, or email articles for individual use. 